\title{
PERGESERAN PARADIGMA DALAM PENDIDIKAN TINGGI HUKUM (Dari Kurikulum Inti dan Institusional ke Kurikulum Berbasis Kompetensi)
}

\author{
Rini Fidiyani \\ Fakultas Hukum Universitas Negeri Semarang \\ E-mail: fidiyani.rini@gmail.com
}

\begin{abstract}
The change of era and labor markets creates demand for graduates college of law must have the necessary competency, whereas the high law education system does not prepare graduates to have competencies that are expected. Therefore, a change from the old curriculum to the Competency Based Curriculum (CBC) needs to be done to address these problems. In CBC, competency mapping, teaching paradigm is also shifting from Teacher-Centered Learning (TCL) to the Student-Learning Center (SCL). Loads lecture materials are also change from the original emphasis on technical expertise (academic/ hardskills) to the non-technical skills (softskills) are balanced. Expectation with the implementation of CBC on the law of science study program, graduates who can compete and have generated competitiveness in the job market.
\end{abstract}

Keyword: Competency Based Curriculum, Student-Learning Center, Teacher-Centered Learning, hardskills, softskills.

\begin{abstract}
Abstrak
Perubahan jaman dan pasar kerja membuat permintaan akan lulusan perguruan tinggi hukum harus memiliki kompetensi yang dibutuhkan, padahal sistem pendidikan tak menyiapkan lulusan untuk memiliki kompetensi yang diharapkan. Oleh karena itu, perubahan dari kurikulum lama ke Kurikulum Berbasis Kompetensi (KBK) perlu dilakukan untuk menjawab permasalahan tersebut. Dalam KBK, kompetensi lulusan dipetakan, paradigma pengajaran juga bergeser dari Teacher-Centered Learning (TCL) ke Student-Center Learning (SCL). Muatan materi perkuliahan juga mengalami perubahan dari yang semula menekankan pada keahlian teknis (akademik/ hardskills) ke arah kemampuan non teknis (softskills) secara berimbang. Diharapkan dengan penerapan KBK pada program studi ilmu hukum, lulusan yang dihasilkan dapat bersaing dan memiliki daya saing di pasar kerja.
\end{abstract}

Kata Kunci: Kurikulum Berbasis Kompetensi, Student-Learning Center, Teacher-Centered Learning, hardskills, softskills.

\section{Pendahuluan}

Salah satu tujuan penyelenggaraan pendidikan oleh sebuah institusi adalah untuk menyediakan dan menghasilkan lulusan yang memiliki kemampuan dan daya saing dalam pencarian, perolehan, dan penciptaan pekerjaan. Pada persoalan daya saing, sayang sekali kondisi sumber daya manusia (SDM) di Indonesia berada pada taraf yang rendah. Laporan terbaru dari World Competitiveness Yearbook 2009, menetapkan daya saing (mahasiswa) kita berada pada peringkat ke 42. Peringkat ini masih lebih rendah di banding dengan negara Asia Tenggara lainnya, yaitu Singapura (ke-3), Ma- laysia (ke-18), dan Thailand (ke-26). ${ }^{1}$ Bahkan kalah dengan Vietnam. ${ }^{2}$ Salah satu sebab dari ren-dahnya daya saing itu terletak pada kurikulum pendidikan tinggi yang masih berbasis pada isi (content based), bukan pada kompetensi.

\footnotetext{
Lihat dalam Tamidi, 2010, Peranan Kurikulum Berbasis Kompetensi (KBK) Terhadap Pembentukan Softskill Mahasiswa, Medan: Fakultas Psikologi Universitas Sumatera Utara, hlm. 1. Lihat juga Dewa Komang Tantra, Kurikulum Berbasis Kompetensi, Makalah pada Kegiatan Penyempurnaan Kurikulum Fakultas Seni Rupa dan Desain, ISI Denpasar, 11 November 2009, hlm. 1.

2 Departemen Pendidikan Nasional, 2003, Pelayanan Profesional Kurikulum 2004, Kurikulum Berbasis Kompetensi, J akarta: Pusat Kurikulum, Balitbang Depdiknas, hlm. 5.
} 
Kurikulum yang content based, menitikberatkan pada pencapaian Indeks Prestasi (IP) dengan indikator kualitas Iulusan mendasarkan pada IPK, lama studi dan predikat kelulusan yang disandang, ${ }^{3}$ padahal IP hanya menggambarkan kemampuan dari aspek kognitif (hardskill), yang dalam dunia kerja masa sekarang dianggap kurang penting dibandingkan dengan kemampuan dari aspek afektif dan psikomotorik yang berupa softskill. Bahkan dari hasil survey, yang dilakukan Pusat Kurikulum Depdiknas terungkap bahwa kunci kesuksesan adalah $80 \%$ mindset dan 20\% technical skill. ${ }^{4}$

Keterpurukan daya saing SDM kita tak lepas dari perubahan yang terjadi pada Abad XXI dan kondisi permintaan pasar kerja yang tak segera direspon oleh penyelenggara pendidikan. Perubahan jaman menghendaki dilakukannya perubahan pendidikan tinggi yang bersifat mendasar, berupa perubahan dari pandangan kehidupan masyarakat lokal ke masyarakat dunia (global), perubahan dari kohesi sosial ke partisipasi demokratis, dan perubahan dari pertumbuhan ekonomi ke perkembangan kemanusiaan. $^{5}$

Salah satu perubahan yang harus segera dilakukan adalah perubahan kurikulum. Kurikulum pada hakekatnya adalah sebuah program yang disusun untuk mencapai tujuan pendidikan, akan tetapi seringkali perubahan kurikulum seringkali hanya berfokus pada pengubahan dokumen saja, dan pelaksanaan pembelajaran, penciptaan suasana belajar, cara evaluasi pembelajaran seringkali tidak berubah. Perubahan kurikulum menjadi keharusan, jika output yang

\footnotetext{
3 Sub Direktorat KPS (Kurikulum dan Program Studi), 2009, Buku Panduan Pengembangan Kurikulum Berbasis Kompetensi Pendidikan Tinggi (Sebuah Alternatif Penyusunan Kurikulum), hlm. 4

4 Bandingkan dengan hasil survey National Association of Colleges and Employers (NACE), USA, 2002, yang menunjukkan bahwa ternyata Indeks Prestasi Kumulatif (IPK) bukanlah hal yang dianggap penting di dalam dunia kerja, jauh lebih penting adalah softskill. Demikian pula dengan penelitian dari Asosiasi MBA dunia yang dilakukan terhadap lulusan program MBA, yang menyimpulkan bahwa softskill lebih berperan dalam peningkatan karir; dan penelitian Hakim (2008) berdasarkan data yang diadopsi dari Harvard School of Business, memberikan gambaran mengenai persentase kemampuan seorang mahasiswa yang diperoleh dari kampus mereka, yaitu 90\%teknis dan sisanya softskill. Tarmidi, op.cit, hlm. 2

5 Sub Direktorat KPS, op. cit, hlm. 1.
}

dihasilkan oleh penyelenggaraan pendidikan telah bergeser, sesuai dengan perkembangan jaman dan tuntutan dari pasar kerja. KurikuIum Berbasis Kompetensi (KBK) diyakini merupakan jawaban terbaik atas perubahan jaman bagi penyelenggaraan pendidikan, bahkan dikatakan oleh Dewa Komang Tantra ${ }^{6}$ bahwa KBK merupakan jawaban untuk mencapai keunggulan bangsa sehingga mampu bersaing di dunia (nation competitiveness).

Hukum atau lebih tepatnya pendidikan tinggi hukum termasuk lambat dalam merespon perubahan yang terjadi. Sampai saat ini belum ada program studi ilmu hukum yang menerapkan KBK secara penuh, dan masih berkutat pada kurikulum inti dan institusional yang telah terbukti tak mengangkat daya saing Iulusan dalam pekerjaan. Keadaan di program studi ilmu hukum ditopang dengan debat yang tiada kunjung habis mengenai pertanyaan apakah pendidikan S1 IImu Hukum itu merupakan pendidikan keterampilan atau keilmuan. Jika mengacu pada apa yang nantinya terumus dalam KBK, jawaban dari pertanyaan itu akan dijumpai dan usailah perdebatan itu. Dengan kata lain, pembuatan dan penerapan KBK di program studi ilmu hukum merupakan suatu keharusan, agar kompetensi lulusan dapat terpetakan sejak awal. Artikel ini berupaya untuk menjabarkan mengenai KBK, pergeseran paradigm, sistem pembelajaran dan konsekuensi metodologis dari penerapan KBK pada program studi ilmu hukum.

\section{Pembahasan \\ Pergeseran Paradigma Pembelajaran di Per- guruan Tinggi dan Pengembangan Kurikulum Berbasis Kompe-tensi (KBK)}

Pembahasan tentang pergeseran paradigma dalam pendidikan tinggi hukum selalu terkait dengan persoalan mengenai landasan filosofis yang memandu beroperasinya sistem pendikikan tinggi hukum. Pada tataran filosofis, maka uraian akan meliputi berbagai basic belief atau world view yang seringkali disangkutpautkan dengan paradigma. Paradigma me-

\footnotetext{
6 Dewa Komang Tantra, Ioc. cit.
} 
rupakan suatu masterpiece yang menakup semua unsur praktik-praktik ilmiah atau ilmu pengetahuan di dalam sejumlah area of inquiry atau bidang studi atau penelitian terspesialisasi. Paradigma juga menggariskan parameterparameter penting mana yang akan diukur, mendefinisikan standar ketepatan yang dibutuhkan, menunjukkan cara bagaimana (hasil) observasi akan diinterpretasi, serta metode eksperimen mana akan akan dipilih untuk diterapkan. ${ }^{7}$

Secara ringkas, paradigm disebut sebagai disciplinary matrix, yakni suatu pangkal, wadah, tempat, cetakan, atau sumber di/dari mana suatu disiplin ilmu pengetahuan dianggap bermula, berasal, berakar, dicetak, bersumber/mengalir, atau dijadikan. ${ }^{8}$ Lain daripadai itu, paradigma dapat dianggap serupa dengan 'pendekatan' atau approach maupun 'tradisi'. ${ }^{9}$ Guna kepentingan penulisan ini, penulis mengambil pemahaman paradigma sebagai suatu cara berfikir yang meliputi asumsi dasar atau teori yang harus dijawab, dan pemahaman paradigma yang cocok untuk hal ini adalah pemahaman paradigma yang dikemukakan oleh Thomas Kuhn, di mana setelah datangnya suatu masa suram dari paradigma lama maka akan muncul (bergeser ke) paradigma baru.

Lemahnya daya saing lulusan perguruan tinggi di Indonesia memerlukan perubahan besar dalam sistem pendidikan tinggi di Indonesia. UNESCO (1998) menjelaskan bahwa untuk melaksanakan empat perubahan besar di pendidikan tinggi tersebut, dipakai dua landasan berupa empat pilar pendidikan dan belajar sepanjang hayat (learning throughout life). Empat pilar pendidikan itu adalah learning to know, learning to do, yang bermakna pada penguasaan kompetensi dari pada penguasaan keterampilan menurut klasifikasi ISCE (International Standard Clasification of Eduacation) dan ISCO (International Standar Classification

\footnotetext{
7 Erlyn Indarti, "Legal Constructivism: Paradigma Baru Pendidikan Hukum dalam Rangka Membangun Masyarakat Madani", J urnal Masalah-masalah Hukum FH UNDIP, Vol. XXX No. 3, Juli-September 2001, hlm. 145.

8 Thomas Kuhn, 1970, The Structure of Scientific Revolution, Chicago: Chicago University Press.

9 W.L. Neuman, 1991, Social Research Methods, London: Allyn and Bacon. Lihat pula pada Erlyn Indarti, loc. cit.
}

of Occipation), dematerialisasi pekerjaan dan kemampuan berperan untuk menanggapi bangkitnya sektor layanan jasa, dan bekerja di kegiatan ekonomi informasi; learning to live together (with others), dan learning to be. Sedangkan belajar sepanjang hayat merupakan wujud dari imperative for democracy; pendidikan multidimensional; munculnya new times, fresh fields; pendidikan at the heart of society; dan kebutuhan sinergi dalam pendidikan. ${ }^{10}$

Saran UNESCO untuk melakukan perubahan besar dalam sistem pendidikan direspon dengan adanya perubahan kurikulum dari konsep Kurikulum Nasional 1994 ke Kurikulum Inti dan Institusional pada 2000 dan dilanjutkan dengan Kurikulum Berbasis Kompetensi 2002. Perubahan kurikulum dari Kurikulum Inti dan Institusional (Kepmendiknas No. 232/U/2000) ke KBK (Kepmendiknas No. 45/U/2002) lebih banyak di dorong oleh masalah-masalah global atau eksternal, yaitu: ${ }^{11}$ pertama, persaingan di dunia global yang berakibat juga terhadap persaingan perguruan tinggi di dalam negeri maupun di luar negeri sehingga perguruan tinggi dituntut untuk menghasilkan lulusan yang dapat bersaing dalam dunia global; kedua, adanya perubahan orientasi pendidikan tinggi yang tidak lagi hanya menghasilkan manusia cerdas berilmu, tetapi juga yang mampu menerapkan keilmuannya dalam kehidupan di masyarakatnya (kompeten dan relevan) yang lebih berbudaya; dan ketiga adanya perubahan kebutuhan di dunia kerja yang terwujud dalam perubahan persyarakat dalam menerima tenaga kerja, yaitu adanya persyaratan softskills yang dominan di samping hardskillnya.

Beberapa kalangan berpendapat bahwa KBK merupakan jawaban jitu terhadap permasalahan mutu pendidikan, sedangkan kalangan lain berpendapat KBK merupakan jawaban yang keliru. KBK menuai popularitas di Amerika Serikat pada tahun 1970-an sebagai dasar untuk pendidikan vokasional bagi tenaga kependidik-

\footnotetext{
${ }^{10}$ UNESCO, Higher Education in the Twenty-first Century: Vision and Action. World Conference on Higher Eduation. Paris, 5-9 October 1998. Lihat pula dalam Sub Direktorat KPS, op.cit, hlm. 1-2.

$11 \mathrm{lbid}, \mathrm{hlm}$. 6-7 dan 8-9.
} 
an. KBK juga berkembang di Inggris dan Wales pada awal 1986, kemudian Selandia Baru, Australia dan Indonesia pada paruh akhir tahun 1980-an. Meski demikian, di beberapa negara KBK menuai berbagai kritik.

KBK sifatnya sangat individualis, menekankan pada outcomes (apa yang diketahui dan apa yang dapat dilakukan), dan prosedurnya sangat fleksibel. Pendekatan kompetensi memperjelas bagaimana outcomes dapat dicapai dengan mutu pencapaian menurut standar nasional maupun internasional. Secara teoretis, KBK meniadakan pembedaan antara "tangan dan pikiran, teori dan praktik, umum dan spesifik dalam pendidikan". ${ }^{12}$ Bagi yang tidak sejalan dengan KBK, mereka menyebut KBK sebagai sesuatu yang sangat reduksionistik, sempit, kaku, teoretis, empiris, dan pedagogis yang sangat tidak memadai. ${ }^{13}$ Meski demikian, keduanya - yang pro dan kontra - setuju apabila kompetensi tersebut dikonsepsikan ke dalam bentuk perilaku (behavioral terms). ${ }^{14}$

Dewa Komang Tantra, ${ }^{15}$ dengan mendasarkan pada mereka yang pro dan kontra KBK, berpendapat bahwa KBK berada di antara mitos dan realita. Disebut mitos - dengan mendasarkan pada pendapat yang kontra KBK - karena KBK hanyalah merupakan sebuah pendekatan kebijakan (policy approach), sebuah mitos dalam pendidikan, yang masih perlu dikaji secara intensif sebelum diimplementasikan. KBK disebut sebagai realita karena KBK bukan saja sebuah pendekatan dalam kebijakan (policy approach), tetapi KBK dapat direalisasikan dalam

\footnotetext{
12 R. Harris, H. Guthrie, B. Hobart dan D. Lumberg, 1995, Competency-based Education and Training: Between a Rock and Whirlpool, Sout Melbourne: MacMillan Education Australia.

${ }^{13}$ C. Chappell, "Quality and Competency-based Education and Training", The Literacy Equation, 71-79. Red Hill, Australia: Queensland Council for Adult Literacy; dan T. Hyland, 1994, Competence, Education and NVQs: Dissenting Perspectives, London: Cassell.

${ }^{14}$ Diuraikan oleh Dewa Komang Tantra bahwa dalam kerangka pikir behaviorisme, kompetensi lebih mudah diurai menjadi perilaku (performance) dalam bidang tugas yang sangat terpisah dan dianalisis secara fungsional menurut peran dan tugasnya. Analisis demikian sangat tepat dijadikan dasar untuk merumuskan kompetensi dan alat ukur yang akan digunakan untuk pencapaian sebuah kompetensi. Lihat dalam Dewa Komang Tantra, op.cit, hlm. 4.

$15 \mathrm{lbid}, \mathrm{hlm} .7$ dan 9.
}

pembelajaran di sekolah untuk mengembangkan kompetensi standar.

Ada beberapa argumen yang perlu dikemukakan dari mereka yang menolak KBK. Pertama, pendekatan KBK yang sangat behavioral sering dicerca karena tidak memperhatikan hubungan antara tugas atribut yang melandasi sebuah perilaku, makna, kemauan, atau disposisi sebuah perilaku atau tindakan, konteks dari perilaku, dan dampak aspek interpersonal dan etis. ${ }^{16}$ Mengingat sifat dunia nyata sangat kompleks dan tidak menentu, ditengarai bahwa tujuan-tujuan yang dirumuskan dalam bentuk perilaku-perilaku terukur tidak dapat sepenuhnya diukur dan diamati sepenuhnya. Rumusan-rumusan perilaku cenderung bersifat diskrit, sehingga ditengarai sebagai sebuah upaya mengatomisasi perilaku yang sebenarnya bersifat holostik dan utuh (intact behaviors). ${ }^{17}$ Lagipula, perilaku yang diklaim telah diukur di anggap sebagai sebuah perilaku akhir (ultimate behavior), walau sesungguhnya menurut pandangan konstruktivis bahwa perilaku tersebut bukanlah yang final, tetapi ia akan direvisi, dikonstruksi ulang, atau diubah menjadi sesuatu yang lebih sempurna. ${ }^{18}$

Kedua, Collins menyebutkan bahwa KBK meningkari hasil penelitian yang pernah dilakukan selama 100 tahun di bidang psikologi, pendidikan, organisasi, maupun dalam bidang kebudayaan. Khususnya, ia tidak sependapat dengan batasan yang digunakan oleh penganut aliran behaviorisme tentang skill dan competence sebagai sebuah perilaku yang bersifat sangat individual dan bebas tata nilai. Padahal, skill dan competence kenyataannya merupakan sebuah hasil konstruksi sosial dan praktik ke-

\footnotetext{
${ }^{16}$ A. Gonczi, " Future Direction for Vocational Education in Autralia Secondary Schools", Australia and New Zealand J ournal of Vocational Education Research 5, No. 1 (May), hlm. 77-108; dan T. Hyland, loc.cit.

$17 \mathrm{~N}$. Jackson, 1994, If Competence is the Answer, What is the Question? A Collection of Original Essay on Curricul um for the Workplace, Geelong: Australia Deakin University, hlm. 135-149.

${ }^{18}$ P. Hodkinson dan M. Issitt (eds), 1995, The Challenge of Competence, New York: Casell; T. Hyland, 1994, loc.cit; dan Dewa Komang Tantra, op. cit, hlm. 5.
} 
budayaan yang aktif dan kreatif. ${ }^{19}$ Lebih-lebih lagi, validitas teknik pengukuran yang didasarkan pada model pembelajaran secara behavioristik sangat problematik sebagai indikator model pembelajaran yang signifikan. ${ }^{20}$

Ketiga, model pengecekan terhadap pemerolehan kompetensi berdasarkan pada teknik checklist yang menandai dicapai/tidaknya dicapainya kompetensi dimaksud dipandang sangat menyederhanakan sebuah persoalan yang sesungguhnya sangat kompleks. Penilaian terhadap pencapaian sebuah kompetensi yang didasarkan pada pencapaian kompetensi minimum sangat tidak memotivasi seseorang untuk mencapai kompetensi standar. Kompetensi minimum hanyalah merupakan tingkatan perilaku yang dapat diterima (acceptable level of competency), bukan berarti kompetensi minimum telah berkesesuaian dengan kompetensi standar yang ditetapkan secara nasional maupun secara interansional (a standard of excellence). ${ }^{21}$

Keempat, Jackson menilai bahwa KBK bersikap sangat birokratis, teralalu rumit, mahal, dan membutuhkan waktu yang banyak untuk mengimplementasikan di sekolah. ${ }^{22}$ Hayland dalam penelitian menyimpulkan bahwa banyak sekolah atau lembaga pendidikan di dunia yang tidak bersedia mengimplementasikan $\mathrm{KBK}^{23}$ Kelima, kendatipun pendekatan kompetensi bersifat kompatibel dengan model pembelajaran kognitif, tetapi KBK tidak cocok diterapkan pada lembaga pendidikan tinggi ${ }^{24}$ karena kompetensi terlalu dibatasi secara sempit dan justru kompetensi meniadakan keberadaan sebuah kurikulum serta mempersempit materi. ${ }^{25}$

\footnotetext{
${ }^{19}$ C. Collin (ed), 1993, Competencies: The Competencies Debate in Australian Education and Training, Curtin: Australian College of Education, hlm. 89.

20 J. Barrie dan R.W. Pace, "Competence, Efficiency, and Organizational Learning", In Human Resource Development Quarterly Vol. 8 No. 4, Winter 1997, hlm. 340; dan Dewa Komang Tantra, op.cit, hlm. 6.

${ }^{21}$ Dewa Komang Tantra, ibid, hlm. 6.

${ }^{22}$ N. J ackson, loc. cit.

23 T. Hyland, "National Vocational Qualifications, Skill Training and Employers' Need", Journal of Vocational Education for the Workplace, Geelong: Australia Deakin University.

${ }^{24}$ T. Hyland, 1994, op. cit, hlm. 336

${ }^{25}$ Dewa Komang Tantra, loc. cit.
}

Terhadap kritik dari penentang KBK ini, para pendukung penerapan KBK dalam penyelenggaraan pendidikan berpendapat sebagai berikut. Pertama, Erridge dan Perry ${ }^{26}$ yakin bahwa "... it gives individuals opportunities to achieve qualifications that relate to required performance in the workplace ...". Bagi keduanya, KBK diyakini memberi peluang bagi seseorang untuk mencapai kualifikasi yang dibutuhkan. KBK diyakini merupakan sebuah rencana dan pengaturan tentang kompetensi dan pemberdayaan sumberdaya secara efisien dan efektif. KBK diyakini dapat memberikan layanan terhadap peserta didik sesuai dengan kemampuan dan potensi yang dimilikinya. Dengan demikian, KBK bukannya menghasilkan lulusan yang memiliki pengetahuan sebanyakbanyaknya, melainkan lulusan yang memiliki kemampuan dan sikap untuk meningkatkan kehidupannya di masyarakat. ${ }^{27}$

Kedua, J ones dan Moore ${ }^{28}$ berpendapat bahwa KBK menerapkan pendekatan kompetensi tunggal (one competency-based approach), yang dapat dengan mudah dispesifikasi menjadi perilkau-perilaku terukur menurut bidang tugas dan garapannya. Ketiga, penetapan kompetensi standar akan memberdayakan individu, sehingga individu tersebut akan mampu melakukan pilihan di antara apa yang harus dipelajari (learning what to be learned) dan bagaimana harus belajar (learning how to learn). Velde dan Hopkins bahkan menambahkan bahwa dalam KBK "... there is less control from bureaucratic power-holder and more decision making made by consumers themselves". Jadi KBK memberikan kesempatan cukup luas kepada siswa untuk mencapai kompetensi yang diharapkan sesuai dengan kemampuan dan potensinya masing-masing. Fleksibilitas pembelajaran dijamin bila menggunakan KBK. Perangkat KBK bukan lagi menjadi kewenangan pusat melainkan kewenangan daerah sesuai

\footnotetext{
${ }^{26}$ A. Erridge dan S. Perry, "The Validity and Value of National Vocational Qualification", British Journal of Education and Work 7 No. 2, 1994, hlm. 140.

27 Dewa Komang Tantra, op.cit, hlm. 7.

${ }^{28}$ L. J ones dan R. Moore, "Appropriating Competence", British J ournal of Education and Work Vol. 8 No. 2, hlm. 78-92.
} 
dengan kondisi dan potensi masing-masing. KBK memberi peluang yang amat besar dan fleksibel bagi guru/sekolah/daerah untuk mengebangkan potensinya masing-masing sesuai dengan kebutuhan dan daya dukung masingmasing. ${ }^{29}$

Keempat, target perilaku yang ingin disasar dirumuskan secara jelas untuk setiap jenjang dan jenis kompetensi. Komponen kompetensi dasar, materi standar, dan indikator pencapaian hasil belajar ditetapkan dan disajikan secara terpadu. Materi-materi yang dibentuk diarahkan pada pencapaian sebuah kompetensi. Materi-materi pelajaran tidak dimaksudkan untuk dihafal melainkan harus diperagakan dan didemonstrasikan agar tercapai kompetensi yang dimaksud. Kelima, guru/dosen diberi kesempatan yang luas untuk berkreasi dan mengembangkan materi-materi pokok secara kreatif agar kompetensi yang ditetapkan sebelumnya terjamin dapat tercapai oleh siswa. Empat pilar UNESCO, yaitu learning to know, learning to do, learning to be, learning to live together diakomodasikan secara integratif dan proporsional dalam pembelajaran siswa. Aspek kognitif, afektif dan psikomotorik diperlakukan sebagai sebuah perilaku yang utuh yang melandasi sebuah kompetensi. Model pembelajaran berorientasi pada siswa (student-oriented learning). Di samping itu, kecakapan bekal hidup di akomodasi dalam pembelajaran secara terpadu. ${ }^{30}$

Keenam, sistem pembelajaran tuntas benar-benar diterapan. Seseorang siswa dapat meneruskan ke jenjang kompetensi yang berikutnya bila ia sudah mencapai kompetensi sebelumnya sesuai dengan batas kompetensi minimum. Sistem manajemen peningkatan mutu dilakukan berdasarkan pada manaj emen berbasis sekolah dan menggalang partisipasi aktif dari semua stakeholders yang potensial. Ketujuh, sistem penilaian yang digunakan bersifat berkelanjutan, yaitu mengacu pada keberlangsungan proses dan sistem penilaian berbasis kelas (classroom-based assessment), yang da-

\footnotetext{
${ }^{29}$ Dewa Komang Tantra, op.cit, hlm. 7-8.

30 lbid, hlm. 8.
}

pat berbentuk test uraian, porto folio, atau tugas. ${ }^{31}$

Kedelapan, KBK menerapkan sebuah kurikulum berdiversifikasi, yaitu dengan mengklasifikasi siswa yang berkemampuan normal, sedang atau tinggi. Siswa yang berkemampuan normal dituntut sebatas memiliki kompetensi minimum, sedangkan siswa yang memiliki kemampuan tinggi dituntut untuk mencapai kompetensi standar. Guru/dosen diberikan kebebasan untuk menetapkan materi yang cocok untuk siswanya. Dengan kebebasan tersebut, guru/ dosen memiliki peluang yang cukup tinggi untuk mengembangkan materi-materi yang memiliki karakteristik lokal. ${ }^{32}$

Tak dapat dipungkiri bahwa KBK selain memiliki keunggulan, juga memiliki kekurangan. Akan tetapi ini tak menyurutkan pemerintah untuk menentukan kebijakan penerapan KBK di semua jenjang pendidikan. Departemen Pendidikan Nasional (sekarang Kementrian Pendidikan Nasional) mulai memberlakukan KBK sejak 2002, yang tertuang dalam Keputusan Menteri Pendidikan Nasional No. 232/ U/ 2000 dan No. 045/ U/2002 yang mengamanatkan penyusunan kurikulum pendidikan tinggi yang berbasis kompetensi untuk setiap program studi oleh kalangan perguruan tinggi yang bersangkutan (bukan oleh pemerintah). Konsekuensinya adalah pengembangan kurikulum diserahkan kepada masing-masing perguruan tinggi (PT), ini sesuai dengan konsep otonomi PT, akan tetapi implementasinya sampai Agustus 2010, belum semua program studi menggunakan KBK, bahkan untuk program studi ilmu hukum, belum satupun menggunakan KBK.

Kurikulum adalah seperangkat rencana dan pengaturan mengenai isi maupun bahan kajian dan pelajaran serta cara penyampaiannya dan penilaiannya yang digunakan sebagai pedoman penyelenggaraan kegiatan belajar mengajar di peruguruan tinggi (Pasal 1 angka 6 SK Mendiknas No. 232/ U/ 2000). ${ }^{33}$ Kompetensi

\footnotetext{
31 Ibid.

32 Ibid.

${ }^{33}$ Bandingkan dengan Kerr dalam Yuli Kwartolo, "Catatan Kritis tentang Kurikulum Berbasis Kompetensi", artikel dalam Jurnal Pendidikan Penabur No. 01/Th.I/ Maret 2002, hlm. 107.
} 
adalah seperangkat tindakan cerdas, penuh tanggungjawab yang dimiliki seseorang sebagai syarat untuk dianggap mampu oleh masyarakat dalam melaksanakan tugas-tugas di bidang pekerjaan tertentu (Pasal 21 SK Mendiknas No. 045/ U/ 2002). Pendekatan kompetensi merupakan suatu cara terbaik untuk meningkatkan kompetensi yang sejalan dengan persyaratan kerja di situs kerja tertentu. ${ }^{34}$

Jadi Kurikulum Berbasis Kompentensi (KBK) ialah kurikulum yang disusun berdasarkan elemen-elemen kompetensi yang dapat menghantarkan peserta didik untuk mencapai kompetensi utama, kompetensi pendukung, dan kompetensi lainnya. ${ }^{35}$ Penetapan kompetensi utama, pendukung dan kompetensi lainnya tak lepas dari perumusan mengenai profil lulusan. Maksudnya adalah profesi apa yang akan diemban oleh lulusan setelah menyelesaiakan pendidikannya. Dari identifikasi profil Iulusan itu maka akan ditentukan kompetensi apa yang harus dipunyainya. Setelah kompetensi itu terbentuk, barulah menyusun pengelompokan mata kuliah berdasarkan elemen kompetensinya, yang terdiri dari landasan kepribadian, penguasaan ilmu dan keterampilan, kemampuan berkarya, sikap dan perilaku dalam berkarya menurut tingkat keahlian berdasarkan ilmu dan keterampilan yang dikuasai; dan pemahaman kaidah berkehidupan bermasyarakat sesuai dengan pilihan keahlian dalam berkarya.

Konsep ini digunakan untuk mengakomodasi kebutuhan masyarakat yang menjadikan perguruan tinggi sebagai tempat pembelajaran dan suatu sumberdaya pengetahuan, pusat kebudayaan, serta tempat pembelajaran terbuka untuk semua. Oleh karena itu dimasukkan strategi kebudayaan dalam pengembangan pendidikan tinggi. Strategi kebudayaan tersebut berujud kemampuan untuk menangani masalahmasalah yang terkait dengan berbagai aspek, yaitu pertama, fenomena anthrophos, dicakup dalam pengembangan manusia yang beriman dan bertaqwa kepada Tuhan Yang Maha Esa dan berbudi pekerti luhur, berkepribadian mantap, dan mandiri serta mempunyai rasa tanggung

\footnotetext{
${ }^{34}$ Dewa Komang Tantra, op.cit, hlm. 4.

35 Tarmidi, op.cit, hlm. 4.
}

jawab kemasyarakatan dan kebangsaan; kedua, fenomena tekne, dicakup dalam penguasaan ilmu dan keterampilan untuk mencapai derajat keahlian berkarya; ketiga, fenomena oikos, dicakup dalam kemampuan untuk memahami kaidah kehidupan bermasyarakat sesuai dengan pilihan keahlian dalam berkarya; dan keempat, fenomena etnos, dicakup dalam pembentukan sikap dan perilaku yang diperlukan seseorang dalam berkarya menurut tingkat keahlian berdasarkan ilmu dan keahlian yang dikuasai. ${ }^{36}$

Sailah menyatakan bahwa kurikulum berbasis kompetensi berupaya untuk mensinergikan hardskills dan softskills. Untuk mengimplementasikannya diperlukan keberanian untuk berubah, kreativitas dosen dalam mengoptimalkan sumberdaya fasilitas dan kemauan serta komitmen yang kuat dari pimpinan perguruan tinggi untuk menerapkannya. Apabila ingin memberikan pendidikan berkarakter dan berkualitas, maka kebiakan dalam mengatur team teaching (tatap muka dalam tim dosen, bukan berarti giliran mengajar dalam satu mata kuliah), mengatur penjadwalan, menyediakan fasilitas ruangan dan alat, komitmen, dan insentif bagi dosen yang memadai. Adapun ciri-ciri kurikulum berbasis kompetensi yaitu; pertama, menyatakan secara jelas rincian kompetensi peserta didik sebagai luaran proses pembelajaran; kedua, materi ajar dan proses pembelajaran dirancang dengan orientasi pada pencapaian kompetensi dan berfokus pada minat peserta didik (Student Centered Learning); ketiga, lebih mensinergikan dan mengintegrasikan penguasaan ranah kognitif, psikomotorik dan afektif; keempat, proses penilaian hasil belajar lebih ditekankan pada kemampuan untuk berkreasi secara procedural atas dasar pemahaman penerapan, analisis, dan

\footnotetext{
${ }^{36}$ Sub Direktorat KPS, op.cit, hlm. 9; Bandingkan dengan pendapat Tyler yang menyatakan bahwa inti kurikulum adalah suatu jawaban secara menyeluruh terhadap beberapa pertanyaan berikut: 1) tujuan-tujuan apa dan maksud-maksud apa yang hendak dicapai oleh sekolah?, 2) kesempatan-kesempatan belajar apa yang dipilih agar terjadi perubahan tingkah laku sesuai dengan harapan?, 3) bagaimana unsur-unsur belajar disusun?, dan 4) bagaimana penilaian untuk mengetahui keberhasilannya?. Keempat jawaban dari pertanyaa inilah yang disebut dengan kurikulum. Yuli Kwartolo, op.cit, hlm. 107.
} 
evaluasi yang benar pula; dan kelima, disusun oleh penyelenggara pendidikan tinggi dan pihak-pihak berkepentingan terhadap Iulusan pendidikan tinggi (masyarakat profesi dan pengguna lulusan). ${ }^{37}$

Perubahan kurikulum berarti juga perubahan pembelajarannya. Dalam kurikulum inti dan institusional, model pembelajarannya didasarkan pada proses transfer of knowledge, di mana dosen/ pengajar menjadi Teacher-Centered Learning (TCL) atau Teacher-Centered Content-Oriented (TCCO). Keadaan ini berubah ke arah penggunaan prinsip Student-Centered Learning ( $\mathrm{SCL}$ ) yang disesuaikan dengan keadaan perguruan tinggi. SCL merupakan suatu proses pembekalan yang berupa method of inquiry seseorang yang berkompeten dalam berkarya di masyarakat. Dengan demikian tampak jelas bahwa perubahan kurikulum dari kurikulum berbasis penguasaan ilmu pengetahuan dan keterampilan (KBI sesuai Kepmendikbud No. 056/ U/ 1994) ke KBK (sesuai Kepmendiknas No. 232/U/2000, mempunyai beberapa harapan keunggulan yaitu luaran hasil pendidikan (outcomes) yang diharapkan sesuai dengan societal needs, industrial/business needs, dan professsional needs; dengan pengertian bahwa outcomes merupakan kemampuan mengintegrasikan intellectual skill, knowledge dan afektif dalam sebuah perilaku secara utuh. ${ }^{38}$

Pola pembelajaran TCL/ TCCO yang berpusat pada dosen kurang memadai untuk mencapai tujuan pendidikan yang berbasis kompetensi. Berbagai alasan yang dapat dikemukakan antara lain adalah: pertama, perkembangan IPTEK dan seni yang sangat pesat dengan berbagai kemudahan untuk mengaksesnya merupakan materi pembelajaran yang sulit dapat dipenuhi oleh seorang dosen; kedua, perubahan kompetensi kekaryaan yang berlangsung sangat cepat memerlukan materi dan proses pembelajaran yang lebih fleksibel; dan ketiga, kebutuhan untuk mengakomodasi demokratisasi

\footnotetext{
${ }^{37}$ Illah Sailah, 2008, Pengembangan Softskill di Perguruan TInggi, Jakarta: Tim Kerja Pengembangan Softskill Direktorat J enderal Pendidikan Tinggi.

${ }^{38}$ Sub Direktorat KPS, op.cit, hlm. 9-10 dan Tarmidi, op.cit, hlm. 4
}

partisipatif dalam proses pmebelajaran di perguruan tinggi.

Pembelajaran ke depan didorong menjadi berpusat pada mahasiswa (SCL) dengan memfokuskan pada tercapainya kompetensi yang diharapkan. Hal ini berarti mahasiswa harus didorong untuk memiliki motivasi dalam diri mereka sendiri, kemudian berupaya keras mencapai kompetensi yang diinginkan. Ketiga alasan pergeseran pembelajaran di atas merupakan alasan di luar esensi proses pembelajaran itu sendiri. ${ }^{39}$ Ini merupakan tugas berat, karena mendorong mahasiswa untuk memotivasi diri sendiripun bukan merupakan hal yang mudah.

Apabila ditinjau esensinya, pergeseran pembelajaran adalah pergeseran paradigma, yaitu paradigma dalam cara ktia memandang pengetahuan, paradigma belajar dan pembelajaran itu sendiri. Paradigma lama memandang pengetahuan sebagai sesuatu yang sudah jadi, yang tinggal dipindahkan ke orang lain/ mahasiswa dengan istilah transfer of knowledge. Paradigama baru, pengetahuan adalah sebauh hasil konstruksi atau bentukan dari orang yang belajar, sehingga belajar adalah sebuah proses mencari dan membentuk/mengkonstruksi pengetahuan, jadi bersifat aktif dan spesifik caranya. Pada paradigma lama, belajar adalah menerima pengetahuan, pasif, karena pengetahuan yang telah dianggap jadi tadi tinggal dipindahkan ke mahasiswa dari dosen, akibatnya bentuknya berupa penyampaian materi/ceramah. Dosen sebagai pemilik dan pemberi pengetahuan, mahasiswa sebagai penerima pengetahuan, kegiatan ini sering dinamakan pengajaran. Dengan pola ini perencanaan pengajarannya (GBPP dan SAP) lebih banyak mendeskripsikan kegiatan yang harus dilakukan oleh pengajar, sedang bagi mahasiswa, perencanaan tersebut lebih banyak bersifat instruksi yang harus dijalankan. Konsekuensi paradigm baru adalah dosen hanya sebagai fasilitator dan motivator dengan menyediakan beberapa strategi belajar yang memungkinkan mahasiswa (bersama dosen) memilih, menemukan dan menyusun pengetahuan serta cara mengembang-

\footnotetext{
$39 \mathrm{lbid}, \mathrm{hlm} .23$.
} 
kan keterampilan (method of inquiry and discovery). Dengan paradigma inilah proses pembelajaran (learning process) dilakukan. ${ }^{40}$

\section{Model Pembelajaran dalam KBK}

Kompetensi dalam proses pendidikan dipahami sebagai gabungan kemampuan kognitif, psikomotorik dan afektif yang tercermin dalam perilaku, atau dalam dunia kerja digunakan istilah gabungan hardskills dan softskills, di mana hardskills dimaksudkan sebagai kemampuan yang berkaitan dengan ilmu pengetahuan dan teknologi (kemampuan teknis), sedang softskills dimaknai sebagai kemampuan interpersolan dan intrapersonal (non teknis). Dalam pembelajaran yang mengarah tercapainya kompetensi, akan dipilih model pembelajaran yang selain dapat menghasilkan hardskills, juga harus dapat menumbuhkan softskills pada anak didik. $^{41}$

Alasan diberlakukannya KBK sendiri karena terjadi perubahan kondisi termasuk pergeseran paradigma. Pergeseran paradigma tersebut dapat dilihat dari beberapa indikator, seperti focus, ownership, expectations, leadership, students, mistakes, classes, dan emphasis. Perubahan pembelajaran dari teacher centered learning menjadi student centered learning, dikarenakan kondisi global (persaingan, persyaratan kerja, perubahan orientasi) yang nantinya akan membawa perubahan pada kompetensi lulusan serta perubahan paradigm belajar dan mengajar yang nantinya diharapkan dapat terjadi perubahan kurikulum yang berdampak pada perubahan perilaku pembelajaran yang akan menghasilkan peningkatan mutu lulusan dan relevansi. ${ }^{42}$

Selama ini terjadi kesenjangan kemampuan lulusan adalah perbandingan prosentase hard skill dan soft skill yang terlalu jauh, yaitu $20 \%$ dan $80 \%$ Padahal faktor yang memberi kontribusi keberhasilan dalam dunia kerja terdiri dari faktor finansial sebanyak $10 \%$ fak-

\footnotetext{
40 Ibid. Silvi Dewijani, Pergeseran Paradigma Ke Arah KBK, Menuj u Perguruan Tinggi yang Berkualitas, makalah pada TA KBK dan SCL di UNSOED Purwokerto, 8-9 Juli 2010, hlm. 19-21.

$41 \mathrm{lbid}, \mathrm{hlm} .37$.

${ }^{42}$ Tarmidi, op.cit, hlm. 5.
}

tor keahlian pada bidangnya $20 \%$ networking $30 \%$ dan $40 \%$ sisanya adalah softskill. Softskill terdiri dari 2 macam, yaitu interpersonals skill dan intrapersonals skills. Interpersonals skills meliputi motivation skills, leadership skills, negotiation skills, presentation skill, communication skills, relationship building, public speaking, dan self-marketing skills. Intrapersonal skills meliputi time management, stress management, change management, transforming beliefs, transforming character, creative thinking processes, good setting dan life purpose, dan accelerated learning techniques. ${ }^{43}$

KBK dengan metode pembelajaran SCL, memiliki beragam model pembelajaran yang dapat digunakan untuk mengembangkan hardskills sekaligus softskills. Model-model tersebut antara lain Small Group Discussion, RolePlay \& Simulation, Case Study, Discovery Learning (DL), Self-Directed Learning (SDL), Cooperative Learning (CL), Collaborative Learning ( $\mathrm{CbL})$, Contextual Instruction $(\mathrm{Cl})$, Project Based Learning, dan Problem Based Learning and Inquiry (PBL). Selain model-model ini, masih ada lain, bahkan setiap dosen dapat mengembangkan model pembelajarannya sendiri. ${ }^{44}$

Small Group Discussion merupakan satu elemen belajar secara aktif dan merupakan bagian dari banyak model pembelajaran $\mathrm{SCL}$ yang lain, seperti $\mathrm{CL}, \mathrm{CbL}, \mathrm{PBL}$ dan lain-lain. Pada model ini, mahasiswa diminta membuat kemlompok kecil untuk mendiskusikan materi yang diberikan dosen atau bahan yang diperoleh anggota kelompok. Pada model simulasi, mahasiswa dibawa ke situasi yang mirip dengan sesungguhnya ke dalam kelas. Pada Discoery Learning, metode belajar difokuskan pada pemanfaatan informasi yang tersedia, baik yang diberikan dosen maupun yang dicari sendiri oleh mahasiswa, untuk membangun pe-

\footnotetext{
${ }^{43} \mathrm{lbid}, \mathrm{hlm} .6$.

${ }^{44}$ Sub Direktorat KPS, op.cit, hlm. 26. Lihat misalnya model pembelajaran yang diintrodusir oleh I Wayan Santyasa dengan nama model pembelajaran inovatif sebagai implementasi KBK. Baca lebih lengkap pada I Wayan Santyasa, Model Pembelajaran Inovatif dalam Implementasi Kurikulum Berbasis Kompetensi, Makalah pada Penataran Guru-guru SMP, SMP dan SMK seJ embrana, J uni-J uli 2004
} 
ngetahuan dengan cara belajar sendiri. Sedangkan pada Self-Directed Learning, mahasiwa atas inisiatif sendiri melakukan perencanaan, pelaksanaan, dan penilaian terhadap pengalaman belajar yang telah dijalani. Dosen hanya bertindak sebagai fasilitator, memberi arahan, bimbingan dan konfirmasi terhadap kemajuan belajar yang telah dilakukan mahasiswa. ${ }^{45}$

Cooperative Learning adalah metode belajar berkelompok yang dirancang oleh dosen untuk memecahkan suatu masalah/kasus atau mengerjakan suatu tugas. Kelompok terdiri atas beberapa mahasiswa yang memiliki kemampuan akademik yang beragam. Collaborative Learning adalah metode belajar yang menitikberatkan pada kerjasama antar mahasiswa yang didasarkan pada consensus yang dibangun sendiri oleh mahasiswa. Contextual Instruction merupakan konsep belajar yang mencoba untuk melakukan link and match antara isi kuliah dengan kehidupan sehari-hari. Project-Based Learning adalah metode belajar yang sistematis, yang melibatkan mahasiswa dalam belajar pengetahuan dan keterampilan melalui proses pencarian (inquiry) yang panjang dan terstruktur terhadap pertanyaan yang otentik dan kompleks serta tugas dan produk yang dirancang dengan sangat hati-hati. Problem-Based Learning/Inquiry adalah belajar dengan memanfaatkan masalah dan mahasiswa harus melakukan pencarian atau penggalian informasi (inquiry) untuk dapat memecahkan masalah tersebut. ${ }^{46}$

Penggunaan metode SCL dalam penerapan KBK memang penuh muatan softskills. Berbagai penelitian yang sejalan dengan pentingnya pengembangan softskills mendukung hal ini, di antaranya berdasarkan hasil beberapa jajak pendapat (tracer study) yang dilakukan perguruan tinggi di Indonesia, kompetensi sarjana di dunia kerja dibagi dua aspek. Pertama, aspek teknis berhubungan dengan latar belakang keahlian atau keahlian yang diperlukan di dunia kerja. Kedua, aspek non teknis mencakup motivasi, adaptasi, komuni-

\footnotetext{
45 Ibid, hlm. 27-28
}

46 Ibid, hlm. 29-30. kasi, kerjasama tim, pemecahan persoalan, manajemen stress, kepemimpinan dan sebagainya. Masing-masing dunia usaha/industri dapat memberikan sederet kompetensi teknis maupun non teknis yang berbeda. Namun pada umumnya, jenis kompetensi non teknis lebih banyak dibandingkan dengan kompetensi teknis. Dalam dunia industri dan akademik, terdapat perbedaan sudut pandang dan pengharapan dari lulusan, oleh karena itu perlu di bangun mind set yang sama dan pengembangan kepribadian atau perilaku. Sebagai contoh, salah satu indikator kebagusan program studi saat ini adalah jika lulusannya memiliki waktu tunggu yang singkat untuk mendapatkan pekerjaan pertama. Namun, industri mengatakan bukan itu, melainkan seberapa tangguh seorang Iulusan untuk memiliki komitmen atas perjanjian yang telah dibuatnya pada pekerjaan pertama. ${ }^{47}$

\section{Penerapan KBK pada Program Studi IImu Hukum}

Bagi penyelenggara pendidikan tinggi hukum, persoalan kurikulum memiliki akar sejarah yang panjang dan perdebatan yang tiada kunjung usai dari masa Rechthogeschool (1909) ke Faculteit der Rechtsgeleerdheiden en Sociale Wetenschappen (1947) sampai ke era Program Studi IImu Hukum. Kurikulum yang mendasari penyelenggaraan pendidikan pada masa-masa itu selalu berganti, seriring dengan perkembangan jaman dan perdebatan mengenai pertanyaan apakah pendidikan tinggi hukum merupakan pendidikan akademik atau profesi. ${ }^{48}$

\footnotetext{
${ }^{47}$ Illah Sailah, loc, cit.

48 Lihat perdebaan ini dalam berbagai tulisan, misalnya Mardjono Reksodiputro, Pembinaan Pendidikan Tinggi Hukum dalam Pembangunan J angka Panjang Kedua (PJ PT II), artikel pada Majalah Hukum dan Pembangunan No. 3 Tahun XXV J uni 1995, Jakarta: FH Ul, hlm. 195-219; Mardjono Reksodiputro, Tahap-tahap Pembinaan Sistem Pendidikan Hukum dalam Pembangunan Jangka Panjang Kedua (PJ P II), artikel pada Majalah Hukum dan Pembangunan No. 4 Tahun XXV Agustus 1995, Jakarta: FH UI, hlm. 291-309; Hikmahanto J uwana, Reformasi Pendidikan Hukum, artikel pada Situs MaPPI, http://www. pemantauperadilan. com/ opini/ 04. REFORMASIPENDIDIKA NHUKUMDIINDONESIA. pdf, akses tanggal 10 Agustus 2010; Soetandyo Wignjosoebroto, Perkembangan Hukum Nasional dan Pendidikan Hukum di Indonesia Pada Era Pascakolonial.
} 
Program studi ilmu hukum merupakan penyelenggara pendidikan hukum yang akan menghasilkan lulusan dengan berbagai macam kompetensi yang harus dimiliki dan dikuasai. Kurikulum pendidikan tinggi hukum saat ini masih mengacu kepada kurikulum inti dan institusional, sehingga peta kompetensi tak dapat dilihat hanya dengan melihat kurikulum. Lagi pula penekanan pada content based, menyebabkan isi kurikulum berkutat pada penyampaian materi kuliah dengan dosen sebagai center-nya. Sehubungan dengan tuntutan perkembangan jaman dan dunia kerja, penyelenggara pendidikan tinggi hukum perlu mengubah orientasi kurikulumnya ke KBK.

Sampai saat ini, belum ada program studi ilmu hukum yang memiliki dan menerapkan KBK secara penuh. Ada beberapa yang sebagian kecil menerapkan KBK, akan tetapi itu tak lebih dari sekadar percontohan. Badan Kerjasama Dekan Fakultas Hukum Perguruan Tinggi seIndonesia, masih mendasarkan pada kurikulum lama, padahal amanat dalam peraturan perundang-undangan sudah harus bergeser ke KBK. Saat ini hanya Fakultas Hukum UGM yang sedang serius menggarap KBK, yang berarti jika tak ada program studi ilmu hukum lain yang berani, FH UGM akan menjadi leader dalam penerapan KBK.

Jika kita melihat perdebatan mengenai pendidikan tinggi hukum, maka KBK akan cocok diterapkan. Sebagaimana dikemukakan oleh A. H. de Wild, bahwa pendidikan hukum adalah khas suatu pendidikan professional tampaknya seperti suatu kebenaran yang sudah jelas dengan sendirinya (selfevident, een waarhaeid als een koe). Dalil bahwa antara apa yang dinamakan pendidikan professional dan apa yang dinamakan pendidikan akademik (pendidikan ilmiah) terdapat suatu perbedaan yang fundamental, tampaknya juga sama sudah diterima secara umum. Suatu pendidikan yang diarahkan untuk mengajarkan (menumbuhkan) sejumlah kemahiran dan pemahaman dengan sasaran pada penerapan "praktis" di kemudian harinya, tampaknya memang sekurang-kurangnya pada pandangan pertama memiliki kekhasan yang berbeda ketimbang pendidikan yang tujuan utamanya adalah mengajarkan pengetahuan teoretis/ilmiah. ${ }^{49}$

Apabila kita perhatikan pendapat A.H. de Wild, maka akan terlihat bahwa pendidikan hukum merupakan perpaduan antara pendidikan professional dan pendidikan akademik. Hal ini tak perlu diperdebatkan lebih lanjut mengingat keduanya saling melengkapi. Akan tetapi dalam konteks KBK, persoalan ini kembali muncul mengingat peta kompetensi yang hendak dicapai lulusan, setidaknya mencakup dua hal tersebut.

Terhadap persoalan ini, ada pendapat menarik dari Hikmahanto Juwana yang berpendapat perlunya pemisahan yang tegas antara pendidikan akademik dan pendidikan profesi. ${ }^{50}$ Jika persoalan ini dipetakan ke jenjang pendidikan (S1, S2, dan S3), maka akan jelas peta kompetensinya, akan tetapi jika hal ini diterapkan pada pendidikan S1, persoalan akan kembali ke masa Rechtshogeschool dengan Faculteit der Rechtsgelleerdheid en Social Wetenschappen di jaman kolonial.

KBK memang berorientasi pada kompetensi yang diperlukan dalam bidang pekerjaan tertentu, akan tetapi tak berarti meniadakan pendidikan yang bersifat akademis. Penyusunan KBK bagi program studi ilmu hukum, pada awalnya perlu diidentifikasikan mengenai kompetensi apa yang harus dimiliki oleh seorang Iulusan. Untuk itu perlu ditentukan profil lulusan atau akan menjadi apa atau profesi apa yang akan dijalani oleh lulusan (misalnya, jaksa, hakim, polisi, pengacara, konsultan dan sebagainya). Dari profil lulusan itu maka dapat ditentukan kompetensi utama, kompetensi pendukung dan kompetensi lainnya (yang di dalamnya terdapat muatan hardskills dan softskills) dari masing-masing profil lulusan itu.

Berdasarkan peta kompetensi itu, maka dapat disusun matrik hubungan antara bahan kajian dengan kompetensi dalam bentuk mata kuliah. Bahan kajian itu meliputi Iandasan ke-

\footnotetext{
${ }^{49}$ A. H. de Wild, Pendidikan Hukum Antara IImu dan Profesi, artikel dalam Majalah Pro J ustitia FH UNPAR Bandung, Tahun XII No. $1 \mathrm{~J}$ anuari 1994, hlm. 54.

50 Hikmahanto J uwana, op. cit, hlm. 20-21.
} 
pribadian, penguasaan ilmu dan keterampilan, kemampuan berkarya, sikap dan perilaku dalam berkarya menurut tingkat keahlian berdasarkan ilmu dan keterampilan yang dikuasai; dan pemahaman kaidah berkehidupan bermasyarakat sesuai dengan pilihan keahlian dalam berkarya.

J ika matriks sudah terbentuk, maka akan dapat dirumuskan mata kuliahnya beserta besaran Sistem Kredit Semester (SKS). Dalam KBK, jumlah SKS pada satu mata kuliah adalah besar atau gemuk (misalnya 6 SKS atau 8 SKS). Ini sebagai konsekuensi dari pemetaan kompetensi yang harus memenuhi semua elemen profil Iulusan yang meliputi hardskills dan softskills. J adi dalam KBK, penyusunan mata kuliah bukan berdasarkan pada keahlian dari dosen atau rebutan mata kuliah atau ingin menjadikan keahlian dosen sebagai mata kuliah tersendiri, akan tetapi lebih kepada competensi apa yang harus dipunyai oleh seorang lulusan.

Kurikulum lama yang saat ini masih mendominasi, masih menggunakan proses pembelajaran yang $\mathrm{TCL}$, di mana dosen masih menjadi aktor sentral dalam transfer of knowledge. Tentu saja pergeseran ke KBK akan menimbulkan guncangan pada awalnya di kalangan dosen, akan tetapi hal ini merupakan sebuah proses, karena setiap perubahan pasti ada resistensi dan perlawanan dari para pembela status quo. Adalah suatu hal yang cukup aneh, jika KBK yang pemberlakuannya menggunakan instrument hukum, kemudian mereka yang mengajarkan hukum justru mengingkarinya. Pengingkaran ini terlihat dari lambannya program studi ilmu hukum merespon pemberlakuan KBK yang telah dimulai 2002, ini berarti sudah delapan tahun proses pengabaian berlangsung.

Jika kita melihat kembali model pembelajaran KBK yang tersebut di atas dengan proses SCL, maka akan sangat cocok untuk studi hukum. Misalnya Small Group Discussion, Simulation, Cooperative Learning, Colaborative Learning, Contextual Learning, dan ProblemBased Learning, khususnya yang berbasis pada pemecahan masalah-masalah hukum yang ada dan berkembang di masyarakat. Dalam hal ini ada satu model pembelajaran hukum yang mencoba untuk memberi jawaban atas visi pendidikan hukum yang menyeimbangkan antara profesionalisme dan pemahaman nilainilai keadilan sosial, yaitu pendidikan hukum klinik (Clinical Legal Education). Model ini mendekatkan mahasiswa (dengan supervisi dari Dosen) untuk ikut serta dalam memecahkan masalah-masalah hukum dengan kemampuan teknik hukum dan melatih kepekaan sosial. ${ }^{51}$

Penerapan KBK pada program studi ilmu hukum, mengingatkan kita pada apa yang pernah diungkapkan Satjipto Rahardjo. la mengemukakan bahwa pendidikan hukum sebaiknya secara sistematis dibicarakan dalam konteks sosialnya dan ini memberikan isyarat bahwa pendidikan hukum sifatnya terbuka untuk menampung dan memantau perkembangan yang berlangsung dalam masyarakat. Seringkali yang terkena imbas dari perubahan sosial yang besar adalah hukum, sehingga dapat dipahami bahwa pendidikan hukum menghadapi persoalan yang besar dan mendasar. ${ }^{52}$

Berdasarkan apa yang diungkapkan oleh Satjipto Rahardjo, maka adalah hal yang naïf jika sampai sekarang pendidikan tinggi hukum belum mengakomodir perkembangan atau perubahan sosial yang terjadi sesuai dengan tuntutan jaman. Tuntutan jaman saat ini adalah kebutuhan akan lulusan pendidikan hukum yang memiliki kompetensi yang sesuai dengan bidang pekerjaan dan ilmu yang diperolehnya dibangku kuliah. Oleh karena itu sudah saatnya perubahan dilakukan, yaitu dengan penerapan KBK pada kurikulum pendidikan ilmu hukum.

\footnotetext{
${ }^{51}$ Lihat penjelasan mengenai model ini pada Open Society Justice Initiative, 2009, Legal Capacity Development Documents Clinical Legal Education: General Overview, J akarta: ILRC.

52 Satjipto Rahardjo, 2009, Pedidikan Hukum sebagai Pendidikan Manusia, Kaitannya dengan Profesi Hukum dan Pembangunan Hukum Nasional, Yogyakarta: Genta Publishing, hlm. 7. Pendapat ini ditentang oleh Hikmahanto, yang mencoba ingin menetralkan tujuan pendidikan hukum dari lingkungan sosialnya, dengan mencoba bagi lulusannya sebanding dengan tujuan pendidikan hukum di luar negeri. Hikmahanto J uwana, op.cit, hlm. 17.
} 


\section{Penutup \\ Simpulan}

Perubahan jaman dan permintaan pasar kerja membutuhkan lulusan pendidikan tinggi hukum yang memiliki kompetensi yang memadai sesuai bidang pekerjaannya. Perubahan sosial ini seharusnya membawa kesadaran pada para penyelenggara pendidikan tinggi hukum untuk segera merubah kurikulumnya agar sesuai dengan tuntutan jaman, akan tetapi yang terjadi adalah mereka masih asyik masyuk dengan kurikulum lama yang terbukti kegagalannya dalam menjawab tantangan jaman. Hukum merupakan salah satu bidang yang terkena imbas dari perubahan sosial tersebut, sehingga perubahan model pembelajaran lama dari kurikulum lama (inti dan institusional) ke Kurikulum Berbasis Kompetensi (KBK) merupakan suatu keharusan dan tak dapat ditunda-tunda lagi. Harapan yang tersimpul dari artikel ini adalah agar lulusan program studi ilmu hukum memiliki kompetensi dan daya saing dalam pasar kerja.

\section{DAFTAR PUSTAKA}

Barrie, J. dan R.W. Pace, Competence. "Efficiency, and Organizational Learning". Human Resource Development Quarterly Vol. 8 No. 4. Winter 1997;

Chappell, C. "Quality and Competency based Education and Training", The Literacy Equation. Year 1996;

Collin, C. (ed), 1993. Competencies: The Competencies Debate in Australian Education and Training. Curtin: Australian College of Education;

Departemen Pendidikan Nasional. 2003. Pelayanan Profesional Kurikulum 2004, Kurikulum Berbasis Kompetensi. Jakarta: Pusat Kurikulum, Balitbang Depdiknas;

Dewijani, Silvi. Pergeseran Paradigma Ke Arah KBK, Menuju Perguruan Tinggi yang Berkualitas, makalah pada TA KBK dan SCL di UNSOED Purwokerto, 8-9 Juli 2010;

Erridge, A. dan S. Perry, "The Validity and Value of National Vocational Qualification", British Journal of Education and Work vol. 7 No. 2. Year 1994;
Gonczi, A. "Future Direction for Vocational Education in Autralia Secondary Schools". Australia and New Zealand J ournal of Vocational Education Research vol. 5 No. 1. May 1997;

Harris, R. et all. 1995. Competency based Education and Training: Between a Rock and Whirlpool, Sout Melbourne: MacMillan Education Australia;

Hodkinson, P dan M. Issitt (eds). 1995. The Challenge of Competence. New York: Casell;

Hyland, T. 1994. Competence, Education and NVQs: Dissenting Perspectives, London: Cassell;

Hyland, T. "National Vocational Qualifications, Skill Training and Employers' Need", J ournal of Vocational Education for the Workplace. 1997;

Indarti, Erlyn. "Legal Constructivism: Paradigma Baru Pendidikan Hukum dalam Rangka Membangun Masyarakat Madani". J urnal Masalah-masalah Hukum. Vol. XXX No. 3 J uli-September 2001;

Jackson, N. "If Competence is the Answer, What is the Question?". A Collection of Original Essay on Curriculum for the Workplace. Year 1994;

Jones, L. dan R. Moore. "Appropriating Competence". British Journal of Education and Work. Vol. 8 No. 2. Year 1995;

Juwana, Hikmahanto. Reformasi Pendidikan Hukum, artikel pada Situs MaPPI, http:// www. pemantauperadilan. com/ opini/ 04. REFORMASIPENDIDIKANHUKUMDIINDONESI A. pdf, akses tanggal 10 Agustus 2010;

Kuhn, Thomas. 1970. The Structure of Scientific Revolution. Chicago: Chicago University Press;

Kwartolo, Yuli. "Catatan Kritis tentang Kurikulum Berbasis Kompetensi", J urnal Pendidikan Penabur No. 01 Tahun I. Maret 2002;

Neuman, W L. 1991. Social Research Methods. London: Allyn and Bacon;

Open Society Justice Initiative. 2009. Legal Capacity Development Documents Clinical Legal Education: General Overview. J akarta: ILRC;

Rahardjo, Satjipto. 2009. Pendidikan Hukum sebagai Pendidikan Manusia, Kaitannya dengan Profesi Hukum dan Pembangunan 
Hukum Nasional. Yogyakarta: Genta Publishing;

Reksodiputro, Mardjono. "Pembinaan Pendidikan Tinggi Hukum dalam Pembangunan Jangka Panjang Kedua (PJ PT II)", Majalah Hukum dan Pembangunan No. 3. Tahun XXV J uni 1995;

------. "Tahap-tahap Pembinaan Sistem Pendidikan Hukum dalam Pembangunan J angka Panjang Kedua (PJ P II)", Majalah Hukum dan Pembangunan No. 4. Tahun XXV Agustus 1995;

Sailah, Illah. 2008. Pengembangan Softskill di Perguruan TInggi, Jakarta: Tim Kerja Pengembangan Softskill Direktorat Jenderal Pendidikan Tinggi;

Santyasa, I Wayan, Model Pembelajaran Inovatif dalam Implementasi Kurikulum Berbasis Kompetensi, Makalah pada Penataran Guru-guru SMP, SMP dan SMK se-J embrana. J uni-J uli 2004;

Sub Direktorat KPS (Kurikulum dan Program Studi). 2009. Buku Panduan Pengembangan Kurikulum Berbasis Kompetensi Pendidikan Tinggi (Sebuah Alternatif Penyusunan Kurikulum). Jakarta: Sub Direktorat KPS;

Tamidi, 2010, Peranan Kurikulum Berbasis Kompetensi (KBK) Terhadap Pembentukan Softskill Mahasiswa, Medan: Fakultas Psikologi Universitas Sumatera Utara;

Tantra, Dewa Komang. Kurikulum Berbasis Kompetensi. Makalah pada Kegiatan Penyempurnaan Kurikulum Fakultas Seni Rupa dan Desain, ISI Denpasar. 11 November 2009;

UNESCO, Higher Education in the Twenty-first Century: Vision and Action. World Conference on Higher Eduation. Paris, 5-9 October 1998;

Wignjosoebroto, Soetandyo. Perkembangan Hukum Nasional dan Pendidikan Hukum di Indonesia Pada Era Pascakolonial, artikel pada situs LSM HUMA, http:// www. huma.or.id/ AnalisaHukum/ Perkem bangan_Hukum_Nasional_dan_Pendidikan _Hukum_di_Indonesia_Päda_Ëra_Pascakol onial_Soètāndyo.pdf;

Wild, A.H. de. "Pendidikan Hukum Antara IImu dan Profesi". Majalah Pro Justitia FH UNPAR Bandung, Tahun XII No. 1 J anuari 1994. 